\title{
Social Downgrading on Consumer Values and Practices: A Transgenerational Perspective
}

\author{
Mercanti-Guérin Maria
}

\begin{abstract}
The aim of this research is to measure the influence of social downgrading on consumer values and practices. Intergenerational mobility is defined as a process leading to a change in social status from parents to children. The first part of this paper presents social mobility and emphasises its multidimensional character. In particular, we detail the different types of objective and subjective mobility. In the second part, we analyse the symbolic and psychological aspects of the acceptance or rejection of social downgrading. We present the results of an exploratory study based on the life stories of a dozen families. It appears that some downgraded individuals do not accept to give up the lifestyle inherited from their childhood and perceive it as an intimate part of their identity. Others, on the contrary, rebuild new identities and modes of consumption based on a "reappropriation of their declassification". This study provides a better understanding of social downgrading by presenting it as a complex process combining the incorporation of a new social status, transgenerational capital and new forms of consumer resistance.
\end{abstract}

Keywords: downward social mobility, inter-generational mobility, transgenerational capital, identity, values, social status

\section{Introduction}

The transmission of consumer practices between generations is the subject of a number of marketing studies (Hansen and al., 2020). It generally focuses on the influence exerted by parents on their children. This influence would explain why certain consumption behaviours persist from generation to generation. The mechanisms of intergenerational transmission and nostalgic connections are all foundations for the construction of transgenerational capital that is expressed through consumption (Ladwein, Carton and Sevin, 2009; Derbaix and Derbaix, 2019).

Nevertheless, very few studies have looked at the rupture that can exist between generations when the youngest experience a social downgrading. Downward generational social mobility is the subject of recent studies in sociology and economics (DiPrete, 2020). The fact that it is no longer perceived as ascending but as 
descending structures a new mode of relationship between generations. As AttiasDonfut and Wolff (2001) point out, it encourages new forms of mutual aid between parents and children but, also, the emergence of protest against precariousness (Shultziner and Kornblit, 2020). Social downgrading appears to generate more profound upheavals that go well beyond family solidarity. It affects the identity of the individual. The break in the transmission of a 'consumption capital' inherited from the family history leads the individual to adopt new values and to redefine his or her relationship with consumption. Furthermore, the concept of social downgrading poses a problem of measurement due to the multiplicity of social statuses (profession, diploma, lifestyle) and the difficulty of comparing lifestyles between generations. Although it has a certain objective reality (Peugny, 2019), social downgrading is mainly considered in its subjective dimension, i.e. the awareness that an individual has of belonging to a social group, or of no longer belonging to it. Finally, the fear of social downgrading represents a subject of study in its own right that has not yet been fully explored. Our objective is to synthesise the research on social downgrading in a direction that is paradoxically still relatively unexplored, that of consumption. Our aim is therefore to address the influence of breaks in the transmission of consumption practices between generations. These breaks affect transgenerational capital in the sense of Ladwein, Carton and Sevin (2009) and could have multiple implications on the behaviour of the downgraded consumer (identity, values, resistant behaviour, relationship with time, etc.).

In the first part, we will address the concept of social downgrading through its different dimensions (objective, subjective, projective). We will see that beyond the strict measurement aspects and the methodological problems raised, the study of downgrading also leads to a number of conceptual debates. In a second part, we will present the methodology used and the first results. In the third part, based on our findings, we will summarise the marketing research perspectives opened up by downgrading.

\section{What is social downgrading?}

\section{Dimensions and measures}

Social downgrading or downward intergenerational mobility is commonly defined as a situation in which children find themselves lower on the social ladder than their parents. Beyond a fairly simple observation of a recent fact lies a complex reality (Mitrea and al., 2020). Downgrading may concern de-skilling (the gap between the level of qualification obtained and the job held) or geographical uprooting. However, it is mostly studied from a generational perspective and raises many questions about the new relationships between generations that it brings about. Why has the individual been unable to maintain the position inherited from his or her parents? Is intergenerational equity under threat? Are the security of destiny and the community of destiny embodied by a virtuous generational dynamic being called into question? (Tosun and al., 2021) The idea of progress and the possible highlighting of the 
singularities of the declassed are studied from the angle of values, preferences or relationship to the future. Peugny (2009) shows that a downward generational trajectory influences political opinions (opposition to liberalism) but also confidence in the redistributive functions of the state. Thus 'downgrading is underpinned by an aspiration for better social opportunities for fulfilment which, if not met, are likely to generate frustration' (Peugny, 2009: 10). Nevertheless, downgrading is seen by some researchers as a real phenomenon but one whose reality is amplified by a false perception that individuals have of their purchasing power or standard of living. Our literature review is therefore divided into three parts. In the first part, we will review the different paradigms of social mobility. In the second part, we will detail the methods for capturing subjective and objective mobility and the different methodologies and measures used. In the third part, we will review the links established by researchers between mobility and consumption and more specifically between downgrading and consumption, given that the literature on the subject is extremely limited. As the perspective of this research is to study downgrading from a generational point of view (intergenerational mobility), we will deliberately not deal with temporary downgrading which may be due to certain accidents in the life course (intragenerational mobility) such as unemployment or divorce.

Three paradigms have been used to understand the phenomena of social mobility: systemic paradigms, semi-individualistic paradigms and hyper-individualistic paradigms.

\section{The paradigms of social mobility}

Systemic paradigms (1) of social mobility consider that social mobility is due to the evolution of the social structure, which is itself strongly influenced by the social division of labour. Society has institutions that select individuals according to its needs, the first of which is to ensure the continuity and reproduction of social structures. According to Sorokin (1927), there are agencies for the distribution of social mobility (mainly the family and the school but also political parties or the church) or selection agencies. Thus, the observed social mobility is structural and not based on individual merit. This theory can be compared with the research carried out by Davis, Moore (1945) and Parsons (1949) for whom social mobility is only a strategic element allowing adjustments within the social structure. For Davis and Moore (1945), these adjustments are based on reward systems that regulate the allocation of important positions to certain individuals.

In contrast, the paradigms that we will call semi-individualistic (2) see social mobility as a product of society which, in order to endure, distributes individuals in a functional manner within the different social classes. Nevertheless, this distribution, while tending to freeze positions, leaves the door open to individual upward trajectories favoured by rewards and reward systems (Lipset and Zetterberg, 1956). As Heeb (2005, p.11) points out, 'the requirement of social regulation, specific to the 
first paradigm, is not denied by these authors, but it would coincide, at least partially, with the individual requirement of social ascension.

Whereas in previous theories the division of labour plays a central explanatory role in mobility, hyper-individualist (3) theories put individual social aspirations back at the centre of mobility. Blau and Duncan (1967) reduce mobility to its individual dimension through two essential values: fulfilment and universalism. Universalism and its corollaries (efficiency, rationality) are said to lead, through technological progress, to an increasing increase in higher positions and greater geographical mobility, weakening family ties seen as obstacles to mobility. Individual selffulfilment, raised to the level of a norm, would push individuals to adopt socially valued behaviours based on the aspiration to social ascension. Consumption is then seen as a sign of ostentatious upward mobility. It allowed a favourable social evaluation and increased the desire of individuals to improve their position.

\section{The genesis of the concept of social mobility and its difficult operationalisation}

Sorokin $(1927,1959)$ is considered the founder of the concept of social mobility. Approached by earlier authors such as Tocqueville, Durkheim or Marx, Sorokin (1927) contributed to the theorisation of this notion by referring directly to a stratified conception of the social structure. This stratification (different from approaches based on castes or social classes in the Marxist sense of the term) shows that classes can be differentiated according to multiple criteria such as nationality, profession, gender or economic, professional, political or cultural criteria. The operationalisation of social mobility should be multidimensional. Thus, Sorokin (1927) defines mobility as "the movement of individuals or groups from one social position to another and the circulation of objects, values and cultural traits among individuals and groups". Its measurement cannot be based on a single observation of occupational positions (Merllié, 1994). However, the study of social positions has never taken into account the cultural dimensions and values as addressed by Sorokin. Moreover, the measurement of social mobility depends strongly on the paradigms to which researchers subscribe.

\section{Measures of social mobility: systemic paradigms and mobility tables}

The analysis of mobility tables (recording changes in social position between generations) is the method of investigation followed by the systems paradigm approaches. This method results in the production of mobility indices. The main mobility indices are summarised in Table 1. 


\begin{tabular}{|l|l|}
\hline Social immobility & $\begin{array}{l}\text { Assigned social status, reproduction or } \\
\text { social heredity }\end{array}$ \\
\hline Vertical mobility & $\begin{array}{l}\text { Change in status in the social hierarchy } \\
\text { between father and child }\end{array}$ \\
\hline Mobility flows & $\begin{array}{l}\text { Difference between total (gross) mobility } \\
\text { and immobility within an age group }\end{array}$ \\
\hline Structural mobility & $\begin{array}{l}\text { Change of social status due to } \\
\text { changes in economic structures (e.g. } \\
\text { tertiarisation) }\end{array}$ \\
\hline Net mobility or circulation & $\begin{array}{l}\text { Difference between gross mobility and } \\
\text { structural mobility }\end{array}$ \\
\hline
\end{tabular}

Table 1: The main mobility indices, adapted from Hope, 1971

A large proportion of the respondents underestimate their social position, even though they have more difficulty in really projecting themselves into an established social situation. Finally, the level of education has an influence on the rather weak concordance between objective and subjective mobility. There is also a link between inter-generational and intra-generational mobility. The feeling of personal advancement during the life cycle leads to a positive overestimation of one's social situation, especially in comparison to that of one's parents.

This difficulty in situating oneself within a social class illustrates, beyond the fragmented (and therefore inaccurate) representation of social class by the socioprofessional category, a certain Weberian vision of social dynamics. There is not necessarily a correspondence between the group of belonging and the group of reference.

The differences between objective and subjective mobility illustrate the difficulty of understanding the extent of downgrading. However, the study of current downgrading can be based on theories of reproduction or social immobility. Bourdieu (1970), Longone (1970) or Boudon (1979) have represented the social structure as a relatively fixed whole where only economic growth can, temporarily, free up places for ascent. Longone (1970) stresses that social mobility is only a reflection of the variability of needs and consumption. Therefore, in times of economic crisis, social downgrading becomes an inevitable phenomenon. It would be all the more inevitable as social fluidity is hampered by the different types of capital that the individual must acquire to ensure mobility. According to Bourdieu (1970), the practices of individuals are socially determined. The mastery of cultural capital or the obligatory acculturation that a worker's child must undergo to change status, the play of habitus unfavourable to the lowest categories, result in the perpetuation of inequalities. Even if Boudon (1979) disagrees with the habitus and a certain social determinism, his hypothesis of the rationality of the actors in the choice or not of studying leads to the persistence of inequalities. 


\section{Social downgrading and effects on individuals}

Terrail (1990), through the life stories of immigrants, paints a picture of downgrading due to geographical uprooting. He notes the importance of housing, the phenomena of regrouping which allows for support from community ties and a rich local life, the emergence of a certain culture of declassification which merges with the ethnic culture, the refusal of fatalism and the appetite for social mobility. Moreover, the competition between the downgraded leads to a distancing between the stabilising proletariat and the sub-proletariat.

Peugny (2009) summarises the effects of social downgrading from both an individual and a collective point of view. For the individual, downgrading can be a source of frustration, all the more so when the original social class is high and the period of study (and therefore investment in acquiring sufficient cultural capital) is long. The pathologies of social promotion described by Boltanski (1992) are pathologies of identity, the individual being torn between two social milieus (the milieu of adoption and the milieu of origin), different cultural norms and values. Downgrading is said to have the same influence, leading to a deconstruction of identity. Social isolation, psychological vulnerability, symptoms described by Peugny (2009) as class neuroses are typical indicators of social mobility. Are they also typical of downgrading? Newmann (1988) shows the link between downgrading and loss of confidence, loss of control, feeling of social disorientation.

\section{Downgrading and generations}

Furthermore, downgrading is said to have a definite influence on interactions within the family sphere: relations between spouses, relations with children. Newmann (1988) notes a reversal of the inter-generational hierarchy. The pivotal generation (the parents) becomes dependent on their ascendants and on the psychological solidity of their children, who are more malleable in accepting a difficult economic situation. The network of friendships shrinks in favour of the extended family. As a result, relations between generations are marked by a sense of injustice. The generation born in the 1960 s sees itself as a sacrificed generation, hence a strong generational consciousness. Older people are considered privileged, but the development of inter-generational solidarity reduces the resentment between generations. Nevertheless, the feeling of dependence on the older generation increases individual frustrations. Bourdieu (1978) notes a structural instability in the representation of social identity. The refusal of social finitude would be reflected more in a personal crisis than in a real questioning of the social system.

Fear of the future is a constant in the consequences of downgrading. It is particularly concerned with the future of the next generation. Researchers insist on the emergence of new values among the downgraded, values that serve as a means of identity identification. The difference in lifestyle is claimed, and personal fulfilment is brought to the forefront of the discourse in comparison with a disappointing professional investment. The meaning of work is redefined either in a hedonistic 
direction (social ties, pleasure of work) or in a utilitarian direction (working to eat). Social success and remuneration take second place to life goals (Peugny, 2009). Resistance or even rebellion against a system perceived as unjust concerns some of the declassed. Finally, competition between the downgraded develops. The group immediately below them is stigmatised and deemed unworthy of benefiting from the redistributive functions of the state. The strongest split is between the active and inactive declassed.

\section{Methodology and summary of results}

Social downgrading is a multifaceted concept with implications that are not only economic. Its impact on the psychology of individuals and family structures deserves to be analysed from a consumption perspective. Furthermore, we wish to study the subjective dimension of downgrading, i.e. the impression of downgrading those individuals may have when they compare their situation with that of their parents at the same age. Thus, our questioning concerns the transmission or rupture of transmission of consumption practices within families when downgrading occurs. (1) What influences does the impression of downgrading have on values and consumption practices? (2) Does the impression of downgrading act as a dilution or reinforcement factor of transgenerational capital? (3) Are the notions of generational mutual aid called into question or, on the contrary, reinforced, and in what area? (4)

It should be noted that we are analysing the influence of perceived downgrading on consumption practices as opposed to objectively measured downgrading. Nevertheless, we consider subjective downgrading as having some reality. It is in itself just another way of assessing downgrading, more focused on the individual than on a purely sociological analysis of mobility between cohorts. In this respect, our approach is similar to that of Blau and Duncan (1967) who measure subjective social mobility based on occupational category, income, degree and housing.

Our sample consists of ten families. The narrowness of the sample is explained by the constraints inherent in the study. Indeed, we had to isolate the individuals in a situation of downgrading. Finally, in order to better understand the transgenerational problem of downgrading, we sometimes interviewed three successive generations. The classification is presented in Table 2 . 
Table 2: Classification of the sample

\begin{tabular}{|l|l|l|l|l|l|l|l|l|l|l|}
\hline Families & F1 & F2 & F3 & F4 & F5 & F6 & F7 & F8 & F9 & F10 \\
\hline $\begin{array}{l}\text { Generation } \\
1\end{array}$ & G1 & G1 & G1 & G1 & $\begin{array}{l}\text { G1/G1bi } \\
\text { s }\end{array}$ & $\begin{array}{l}\text { G1/G1bi } \\
\text { s }\end{array}$ & G1 & G1 & G1 & G1 \\
\hline $\begin{array}{l}\text { Generation } \\
2\end{array}$ & G2 & G2 & G2 & G2 & G2 & G2 & G2 & G2 & G2 & G2 \\
\hline $\begin{array}{l}\text { Generation } \\
3\end{array}$ & G3 & & & G3 & G3 & G3 & & & G3 & \\
\hline $\begin{array}{l}\text { Parents } \\
\text { referrers }\end{array}$ & P & P & P & GP & GP & GP & P & P & P & P \\
\hline
\end{tabular}

\section{Caption:}

F, family number, G1 (between 25 and 55), G2 (between 55 and 65), G 3 (over 65) Referring parents: P for parents, GP for grandparents

Principal respondent: in bold

For each family, we distinguished a main respondent identified as the downgraded individual. For some families, the spouse was included in the study. The interviews took place in as informal a setting as possible (usually at home). The structure of the interview is closer to a 'lifestyle' type of analysis, and the duration of the exchanges, for some respondents, represents around ten hours.

The themes addressed for the main respondent were as follows:

The perception of downgrading (impressions gathered on past lifestyles compared to the one lived today, social success, leisure, housing...). The generation of reference varies according to the individuals, some naturally comparing their situations to their grandparents, others to their parents. Individuals who take their grandparents as a reference are generally individuals who experienced the beginning of the decline as children.

The kinship network and the kinship network of the potential spouse, mutual aid relationships

Level of education, educational and professional background, sibling status, marital status

Consumption from all angles (household equipment, budget priorities, housing, food, clothing, holidays, etc.)

It should also be noted that our sample contains a fairly low degree of diversification of social backgrounds. As Chauvel (1998) has shown, social downgrading mainly affects the middle classes. Thus, the families selected are essentially from the middle or upper classes. Furthermore, we were able to understand the difficulty of reasoning in terms of socio-professional categories. The use of individual interviews with 
different generations allowed us to cross-reference the subjective declarative statements of the younger generations describing their previous lifestyles with the more objective discourse of the older generations. The subjective measure of downgrading was thus corrected, to a lesser extent, by cross-referencing the perception of the individuals studied with the perception of previous generations.

As a result, we eliminated individuals whose downgrading was insufficiently proven, as the perception of downgrading was closer to the fear of downgrading than to actual downgrading.

The recurring themes were categorised and theorised in an iterative process (Miles and Huberman, 1994). In addition, we identified categories on the couple argument/predicate (what is talked about, what is said about it) following the example of Ladwein, Carton and Sevin (2009).

\section{Summary of results}

The results of this research show that different individuals can perceive social downgrading very differently. Some people, while aware of the difficulties of their lives compared to their parents' lifestyles, develop a strategy of refusing, not the downgrading itself, but its signs. Others accept their downgrading and see it as an opportunity to change their lives and references.

The results show that it is the consumer's values that are most affected by downgrading. Changes in the perception of time, external signs of wealth, and the meaning of consumption (taken in its ontological character) are found in the framework of analysis of consumer values as described by Holbrook (1999). Certain values are favoured by consumers who reject the signs of their downgrading, namely the values of status, esteem, aesthetics and play. Others are prevalent among consumers who accept their downgrading, namely the values of ethics, spirituality, efficiency and practicality. There is also a difference between active and reactive value in these two populations. Active value (which requires mental or physical activity on the object, a transformative activity) is present in the downgraded individuals.

Concerning preferences, Bourdieu (1970) establishes a link between aesthetics, linguistic, cultural and educational field and social class. Culture would be associated with knowledge and therefore with social power. Taste and food would be dependent on social structure. Consumer preferences would therefore be class preferences and would perpetuate a certain social immobility.

Individuals who refuse to be downgraded often mention education as a market good. It is taken care of by the previous generation, which also looks after the culture and leisure activities of its grandchildren. The use of paid tuition (to prevent the next generation from being downgraded as well) is the responsibility of the most privileged generation. The downgraded are, in a way, denied their ability to pass on 
to their descendants the cultural or artistic preferences of their former group. Generational mutual aid is not only economic, but also, and above all, the preservation of cultural capital.

Faced with downgrading, consumers therefore develop two radically different types of strategy. For individuals who refuse the signs of downgrading, transgenerational capital in the sense of Ladwein, Carton and Sevin (2009) represents their only point of identity anchorage. This transgenerational capital is nourished by 'nostalgic connections of transmissions' (Ladwein, Carton and Sevin, 2009). However, whereas nostalgic connections are described as being based on emotions or on particular events, rituals (Miller, 1998), the nostalgic references of the declassed are centred on exceptional items of consumption, the items with the strongest sign value. Transgenerational capital is the subject of a family mythology, even a sacredness. For individuals who accept downgrading, it is seen as a way of affirming their autonomy in relation to the family traditions of the previous generation. It is, in a way, a tool for reappropriating one's own identity. The phenomena of rejection of consumption habits are widely described in the literature (Heckler, Childers and Arunachalam, 1989; Kaufmann, 1992) and are presented as dependent on the parent-child relationship. In the case of downgrading, autonomy from family consumption practices is not chosen but suffered. Nevertheless, it leads to intergenerational conflicts due to differences in lifestyle between parents and children who have been downgraded.

Transgenerational brands play an important role in the discourse of the declassed. The transgenerational clothing marks retained by individuals who refuse to accept signs of declassification have a precise function: to prolong the social position inherited from their parents through their status value. For individuals who accept the downgrading, transgenerational brands are rejected or abandoned without regret. In particular, we would cite classic retail brands in favour of hard-discount and clothing brands.

Thus, the identification of the consumer with a brand depends on his relationship to the group (Bezes and Mercanti-Guérin, 2017).

In the case of downgrading, some consumers who disassociate themselves from family consumption practices discover brands through downgraded friends. These so-called downgrading peers play a secondary socialisation role, replacing the primary socialisation carried out by the family. This secondary socialisation takes place, in particular, through social networks and publications shared by friends (Mercanti-Guérin,2008; Mercanti-Guérin and Vincent, 2016) .

\section{Values of sign versus values of meaning}

Similarly, the values of signs are favoured in the first population whereas the values of meaning are preferred in the second (sense of ethical consumption, sustainable, natural food, rediscovered traditional culinary and food practices). 
To illustrate our point, we will use the example of food consumption and credit. With regard to food consumption, individuals who accept downgrading often refer to the use of natural products. As Desjeux (2000) and Thevenot (2008) point out, naturally evocative objects serve the imagination and develop routines of reassurance and the search for meaning. The implicit codes that organise behaviour (Desjeux, 2000) have to be rebuilt, as it were, since the declassified individual can no longer consume in the way he or she was taught by family practices.

Concerning credit, which is one of the themes raised by individuals refusing the signs of downgrading, there is a link between indebtedness and locus of control. Roland-Levy (1998) shows that individuals with an external locus of control tend to borrow, whereas individuals with an internal locus of control reject credit. For some, debt appears to be a means of preserving their status but, beyond that, it represents a remedy, a transitory solution to the fall in living standards. The resumption of control over their lives and the denial of their responsibility for their situation are particularly illustrated by recourse to credit, which is experienced as harmless and justified by the acquisition of goods "that one cannot do without" because they are essential for the preservation of self-esteem.

\section{Conclusion, research directions and limitations}

The managerial interest of our research lies, essentially, in taking better account of the sectoral aspect of downgrading. Furthermore, the research avenues opened up by intergenerational downgrading are extremely numerous.

The rupture in transgenerational capital is one of the most visible effects of downgrading. This research represents an axis of development for the study of this concept. It allows for a representational approach, i.e. a cross-generational view, even if we wanted to place ourselves mainly on the side of the downgraded. The beginning of a trigenerational analysis (grandparents, parents, children) also offers interesting research perspectives. Indeed, the grandparents/children relationship is mainly studied from the point of view of mutual aid and not very much from the point of view of the transmission of forgotten family values such as savings. Trends in deconsumerism could be analysed from a generational and longitudinal perspective.

Conceptual clarifications and measures of objective and subjective downgrading and fear of downgrading

Furthermore, the fear of downgrading (and not downgrading itself) is a field of investigation to be taken into account. The measurement of downgrading is, as we have seen, the subject of much debate. It concerns the reductive nature of objective downgrading estimates, the contested validity of subjective downgrading measures. A conceptual clarification of downgrading, through its different measures, should be pursued. The study of the fear of downgrading could be pursued by relating this concept to certain enduring psychological variables (widely incorporated in preference models or persuasion models). 
Social class and consumer behaviour: a rediscovery?

Fisher (1987) noted that, despite a long tradition of authors, the concept of social class has been relatively neglected in consumer behaviour in favour of fuzzier concepts such as lifestyles. However, the study of social classes from a marketing perspective would be justified for several reasons. Social class is a useful construct for understanding both the variations in resources that limit consumer choice and the preferences of consumers. In the context of limited resources, utility maximisation becomes unavoidable. Social class is an indicator of social ties. The so-called affluent classes have more social capital (friends, extended relationships) than the more disadvantaged classes (centred on the family). We can add that the social link is even more complex when there is downgrading, since accepted downgrading leads the individual to establish relationships among the downgraded, therefore outside the family framework and outside his or her social group of reference. This makes marketing policies based on virality and word of mouth more complex.

\section{Transgenerational brands versus generational brands}

The disruption of identities would lead in certain cases of declassification to a blurring of identity or, on the contrary, to the birth of another identity. The place of transgenerational brands could be questioned. The characteristic of transgenerational marks is that they affect several generations equally. For Heilbrunn (1999), transgenerational brands redefine the power games between generations since they contribute to the empowerment of children. They upset the established order of generations. In the case of downgrading, transgenerational brands are no longer part of the consumption heuristics. Either some of them turn out to be unattainable for the consumer, or they symbolise a mode of family consumption to be rejected. The future would be for generational brands, emblematic of new modes of consumption that break with previous ones.

\section{Jealousy and generational comparison, a reappraisal of frustration theory}

The comparison between generations of different living standards remains a possible reason for the dilution of the social body (Peugny, 2009). Furthermore, the disappointment caused by the social position of the downgraded, which is lower than what they could have expected, is undoubtedly a source of frustration. The frustration theory popularised by Amsel (1992) represents an interesting avenue for marketing research. It shows that, in the case of strong frustration, individuals "overreact" in order to obtain the deserved reward. It is as if the efforts made to obtain a reward were not enough, and the individual would re-evaluate the means used upwards. In the case of the downgraded, this re-evaluation of resources is done by over-investing in the children's school work. The market for tutoring should therefore grow more rapidly in a society affected by downgrading.

To conclude, intergenerational downgrading represents an extremely rich and varied field of research for marketing. Still marked by a strong sociological dimension, it 
should find in the years to come a place of its own, both in generational marketing and in consumer behaviour.

\section{References}

[1] Amsel A. (1992), Frustration theory - many years later, Psychological Bulletin, 112, 396- 399.

[2] Attias-Donfut C. and Wolff F.C. (2001), The subjective dimension of social mobility,

[3] Population, 56, 6, 919-958.

[4] Bezes, C., \& Mercanti-Guérin, M. (2017). Similarity in marketing: Scope, measurement, and fields of application. Recherche et Applications en Marketing (English Edition), 32(1), 83-105.

[5] Blau P. and Duncan O.D. (1967), The American occupational structure, New York, Wiley.

[6] Boltanski L. (1992), Les cadres. La formation d'un groupe social, Paris, Editions de Minuit. Boudon R. (1979), L'inégalité des chances, Paris, Librairie Hachette, Pluriel.

[7] Bourdieu P. (1970), La reproduction, éléments pour une théorie du système d'enseignement, Paris, Editions de Minuit.

[8] Bourdieu P. (1978), Classement, déclassement, reclassement, Actes de recherche en sciences sociales, 1-22.

[9] Chauvel L. (1998), Fluidité et espace social : mobilité intergénérationnelle nette, distance sociale des PCS (Professions et catégories socioprofessionnelles) et multidimensionnalité des hiérarchie, Cahier de l'Observatoire sociologique du changement, 22.

[10] Derbaix, C., \& Derbaix, M. (2019). Intergenerational transmissions and sharing of musical taste practices. Journal of Marketing Management, 35(1718), 1600-1623.

[11] DiPrete, T. A. (2020). The Impact of Inequality on Intergenerational Mobility. Annual Review of Sociology, 46, 379-398.

[12] Fisher J.E. (1987), Social class and consumer behavior: the relevance of class and status,

[13] Advances in Consumer Research, 14, 492-496.

[14] Hansen, A. R., \& Jacobsen, M. H. (2020). Like parent, like child: Intergenerational transmission of energy consumption practices in Denmark. Energy Research \& Social Science, 61, 101341.

[15] Heckler S.E., Childers T.L. and Arunachalam R. (1989), Intergenerational influences in adult buying behaviors: an examination of moderating factors, in T.K. Srull (coord), Advances in Consumer Research, 16, Provo, UT, Association for Consumer Research, 276-284.

[16] Heeb J-L. (2005), De la stratification sociale à la mobilité, une analyse du positionnement professionnel perçu, PhD thesis, University of Lausanne, Faculty of Social and Political Sciences, Lausanne. 
[17] Heilbrunn B. (1999), Les marques transgénérationnelles, Décisions Marketing, 18, 81 -84. Holbrook M.B. (1999), Introduction to consumer value, in Holbrook M.B (coord.), Consumer Value. A framework for analysis and research, Routledge Interpretive Marketing Research, 1- 28.

[18] Hope K. (1971), Social mobility and fertility, American Sociological Review, 36, 6,1019 -

[19] 1032.

[20] Kaufmann J.-C. (1992), La trame conjugale. Analyse du couple par son linge, Paris, Nathan. Kingsley D. and Moore W. (1945), Some Principles of Stratification, American Sociological Review, 10, 242-249.

[21] Ladwein R., Carton A. and Sevin E. (2009), Le capital transgénérationnel : la transmission des pratiques de consommation de la mère vers sa fille, Recherche et Applications en Marketing, 24, 1-27.

[22] Lipset S.M. and Zetterberg H. (1956), A theory of social mobility, Transactions of the Third World Congress of Sociology, International Sociological Association, 155-177.

[23] Mercanti-Guérin M. and Vincent M, (2016), Publicité digitale, Dunod.

[24] Mercanti-Guérin M. (2008), Perception d'une annonce créative par le consommateur: construction et validation d'une échelle de mesure, Recherche et Applications en Marketing (French Edition), 23(4), 97-119.

[25] Merllié D. (1994), Les enquêtes de mobilité sociale, Paris, PUF.

[26] Miles M.B. and Huberman M.A. (1994), Qualitative Data analysis (2nd ed.), Thousans Oaks, CA, Sage

[27] Miller M.B. (1998), A theory of shopping, Cambridge: Polity Press.

[28] Mitrea, E. C., Mühlböck, M., \& Warmuth, J. (2020). Extreme pessimists? Expected socioeconomic downward mobility and the political attitudes of young adults. Political Behavior, 1-27.Parsons T. (1964) (original 1949), Essays in sociological theory, New York, Free Press. Newman K. S. (1978), Falling from grass the experience of downward mobility in the american middle class, New York, Free Press.

[29] Peugny, C. (2019). The decline in middle-skilled employment in 12 European countries: New evidence for job polarisation. Research \& Politics, 6(1), 2053168018823131

[30] Roland-Levy C. (1998), Psychologie économique de la consommation et de l'endettement,

[31] Psychologies économiques, Paris.

[32] Shultziner, D., \& Kornblit, I. S. (2020, June). French Yellow Vests (Gilets Jaunes): Similarities and Differences With Occupy Movements. In Sociological Forum (Vol. 35, No. 2, pp. 535-542).

[33] Sorokin P. (1927), Social Mobility, New York, Harper and Brother.

[34] Sorokin P. A. and Lunden W. A. (1959), Power and morality: who shall guard the guardians?

[35] Boston, MA: Porter Sargent Publishers. 
[36] Tosun, J., Pauknerová, D., \& Kittel, B. (2021). Intergenerational Transmission of Economic Self-Sufficiency: An Introduction. In Intergenerational Transmission and Economic Self-Sufficiency (pp. 1-27). Palgrave Macmillan, Cham.

[37] Terrail J.-P. (1990), Destins ouvriers, la fin d'une classe? Paris, PUF, 1990.

[38] Thevenot G. (2008), La consommation des produits naturels: quelques éclaircissements conceptuels, Proceedings of the Venice Congress, Venice. 